\title{
Understanding Neoliberalism, Media and the Political: An Interview with Sean Phelan ${ }^{1}$
}

\author{
SIMON DAWES, Université Paul Valéry, Montpellier, France
}

SEAN PHELAN, Massey University Wellington, Aotearoa New Zealand

\begin{abstract}
In this interview, Sean Phelan discusses the differences between 'ideological' and 'postideological' or 'post-political' neoliberalism, and sets out his own approach to critiquing neoliberalism, which draws on Laclau and Mouffe's discourse theory and Bourdieu's field theory. Arguing for the benefits of a comparative cross-national approach, he illustrates examples of 'actually existing neoliberalism' in UK, US, Ireland and New Zealand contexts. Phelan concludes the interview by suggesting potential sites of cultural politics and the possibility of a radically different kind of media and political culture.
\end{abstract}

\section{KEYWORDS}

Chantal Mouffe, Discourse, Ernesto Laclau, Logics, Neoliberalism, Pierre Bourdieu, Political.

SIMON DAWES: In your recent book, Neoliberalism, Media and the Political (2014) which will be published in paperback later this year - you present studies of particular aspects of neoliberalisation in Ireland and New Zealand, as well as in the more well-documented contexts of the UK and the US. What does this comparative cross-national approach reveal that a focus on a particular national context might miss?

SEAN PHELAN: I guess the main benefit of a comparative approach is that it helps us to better grasp how neoliberalization has been articulated differently in different national and cultural contexts. It encourages caution about quickly appealing to a unitary "neoliberalism", without exploring how that abstract conceptual thing has assumed different political forms and shapes at odds with the image of a monolithic ideology and formation. At the same time, a comparative approach allows us to see the similarities and commonalities between contexts, thus keeping in check an inverse tendency that can exaggerate the uniqueness of each empirical context and which, taken to its polemical extreme, starts to mock any talk of a universal(izing) neoliberalism. My book tries to explore some kind of middle ground between these two tendencies - between a conceptually subsumptive approach that sees nothing other than neoliberal regimes and practices, and empirical approaches that over-privilege the

\footnotetext{
${ }^{1}$ This interview is part of a special section of interviews on 'Neoliberalism, Media and Power', edited by Simon Dawes and also featuring interviews with Des Freedman and Terry Flew. Available at: http://ojs.meccsa.org.uk/index.php/netknow/issue/archive
} 
immediate national context. I find this to be a more productive way to theorize neoliberalism, even if it perhaps risks seeming wishy-washy (a dreaded "third way"!) in light of the antagonisms that structure debates about the concept.

SIMON DAWES: For your chapter on the UK, you focus on the British press's "fantasmatic construction" of enemies of press freedom in response to the Leveson Inquiry. How do you see this as a particularly neoliberal response to the perceived "threat" of press regulation? To what extent is it, for instance, "neo" - i.e. different from a classically "liberal" response?

SEAN PHELAN: The chapter on Leveson is the one that reflects on the relationship between neoliberalism and liberalism most explicitly, though the book examines a wider liberal tradition in only a summary way. I'm not a media historian, but, in one respect, the hegemonic discourse of press freedom today seems continuous with a classical liberal tradition, in that freedom is still primarily understood in negative, individualistic and economic terms - as basically freedom from an oppressive state. My chapter tried to supplement that frame by exploring the resonances between the representation of the state in critiques of Leveson and the representation of the state in the work of neoliberal intellectuals like Friedrich Hayek and Milton Friedman. This is where the argument gets more interesting, I think. Because, contrary to shorthand definitions of neoliberalism that assume an opposition between state and market, what we see in Hayek, especially, is an aversion to a particular kind of state, namely a socialist state that seeks to subordinate state and legal institutions to some overriding moral or political objective. This coercive state is contrasted with Hayek's prescriptive view of how the state should comport itself, by establishing a legislative regime to enable the "spontaneous order" of the market. In Hayek's state-market complex, moral decisions are displaced onto individual market agents (and the anthropomorphic figure of "the market"), rather than articulated in what he saw as some epistemologically spurious, and inherently totalitarian, notion of the collective good.

The bigger point I wanted to highlight here, and which in retrospect I could have brought out more in the overall framing of the book, is the negative character of neoliberal(ized) regimes and subjectivities, by which I mean that a lot of neoliberal rhetoric is staged as a dispute with its ideological Other(s). This negatively constituted identity, or to use Laclau and Mouffe's term "antagonistic" identity, is open to different articulations, some more ideologically literate than others. It can take the form of aggressively ideological discourses that self-consciously reject socialism and social democracy. Or it can take the more fragmented (but arguably more politically useful) form of a mediatized public mood that hates politics and "do-gooder", "sanctimonious" types who know what's best for the rest of us. One of the general failings in the neoliberalism literature, I think, has been to presuppose a world of committed neoliberal subjects, who evangelize about the miraculous power of the free market and so on. My hunch is that neoliberal regimes are often most effective strategically when they cultivate a politics of disidentification with collectivist impulses, and perhaps they are more effective again when they eschew a simple-minded posture of ideologically celebrating the market. The dominant 
political and media mood becomes one of pragmatically and fatalistically accepting the horizons of the existing social order (Mark Fisher's (2009) work on "capitalist realism" is one influence here), even when people can easily cite examples of the destructive effects of markets and capitalism.

To bring the point back to Leveson, clearly much of what was going on in the media can be explained by the desire of the right-wing press to smear the Inquiry in all kinds of outrageous ways, by fostering the impression that the UK was on the verge of a totalitarian takeover. By drawing on the concept of the "fantasmatic", I simply wanted to highlight the psychic and ideological continuities between the media representation of some of Leveson's most high profile supporters, and Hayek's representation of the socialist intellectual. In both cases, all kinds of wicked motivations are projected onto a fantasmatic Other that are officially justified in the language of public morality, but which really amount to little more than an ideological cover story for the intellectual's self-interested desire to universalize their own moral and political prejudices. It is in this sense, I think, that we can usefully talk of a neoliberalization of press freedom rhetoric. The subjectivities appealed to, and discredited, by the anti-Leveson front were all part of an ideological common sense, already textured into the rationality of neoliberal regimes.

SIMON DAWES: You distinguish between "ideological neoliberalism" and its political capture in the 1970s-1980s, on the one hand, and pragmatic, "post-political" or "postideological" neoliberalism, on the other. Could you explain this more recent variant?

SEAN PHELAN: Let me preface my answer with two caveats. First, the book does set this division up in a way that suggests a historical chronology, but it would be a mistake to not recognise that these two tendencies can be at work in the same historical moment. And, second, even though I construct a distinction between an ideologically antagonistic neoliberalism and a post-ideological neoliberalism, I treat both discourses as ideological in the sense that both seek to universalise assumptions that are particular and contestable. In that respect, I follow the assumptions of classic ideology critique by treating the explicit disavowal of ideology as the example par excellence of ideology at work.

The notion of a post-political or post-ideological neoliberalism had its origins in my attempt to make sense of how the Irish case differed from other neoliberal regimes. It seems ridiculous to observe this now given that Ireland has been widely cited as an exemplar of neoliberal capitalism since the 2007-2008 financial crisis. But one of the most salient tendencies among Irish political and media elites of the 1990s and early 2000s was to represent the Irish case as an anti-ideological story, because it eschewed the aggressive "free market" identity associated with 1980s exemplars like Thatcher and Reagan. Contrary to Thatcher's union-bashing politics, the Irish growth model was organised around a corporatist architecture that gave various interest groups, including the main trade unions, the status of "social partners". From the perspective of its official self-image and nomenclature, it 
therefore signified a pragmatic marriage of the economic and the social, quite different from an archetypal Thatcherite hostility to "society". In that respect, Irish neoliberalism had more in common with the ordoliberalism of post-war Germany and the Third Way neoliberalism of Blair and others, which were similarly avowed as transcending ideological antagonisms between state and market, market and society.

Now, the most obvious critical response to the Irish case is to dismiss this narrative as ideological nonsense - merely self-serving camouflage and mystification that is enabled by an alliance of political and business elites and legitimized by corporate media institutions. There's clearly something in that explanation. However, instead of dismissing the official narrative (and enacting a mode of critique that is energized by the feeling of "well, that's just ideological bullshit"), I take a different tack and ask how are these representations made possible and, more specifically, how are they made possible in media spaces? This opens up a line of thought that explores the affinities between a neoliberal habitus that disavows ideology and a journalistic habitus that does the very same thing, in a spirit reminiscent of the classic Birmingham School work of the 1970s. The concept of post-ideological neoliberalism is therefore partly my attempt to better understand what neoliberalism looks and feels like when it is translated into the rationality, dispositions and sensibilities of mediated spaces.

SIMON DAWES: You're critical of the tendency among media scholars to disparage rather than try to understand neoliberalism, and you take issue with the reduction of neoliberalism to a unitary ideology imposed from outside. How does such reductionism obfuscate our understanding of neoliberalism? Would you go as far as to say that it even hampers an effective critique? And should we even dispense with the term, or is it necessary to continue using it as an object of critical analysis, albeit in some qualified way? How do you recommend we see neoliberalism?

SEAN PHELAN: I do think there is a tendency in critical work on neoliberalism, in media studies and elsewhere, which simply denounces the wickedness and idiocy of neoliberalism, without offering much insight into why this "stupid ideology" gained such cultural and political power. Or the story of neoliberalism is told in a way that, as you put it, is too reliant on the image of a "unitary ideology imposed from outside": an ideological project driven by elite political and corporate interests, rather than a heterogeneous and fragmented formation that is embedded in practices and regimes that most of us are entangled in. The governmentality literature does interrogate the notion of a monolithic top-down ideology, but even here there can be a tendency to construct a social world that is colonized by neoliberalism and prototypical neoliberal subjects. I try to counter these tendencies by invoking the concept of neoliberal logics, which are always hegemonically articulated with other social and political logics. It's a simple point really, but the basic impulse is to formulate a critique of neoliberalism that avoids reducing the world to the category of neoliberal; critique partly becomes a labour of finding other ways of naming, or at least potentially naming, empirical phenomena. I think the tendency to construct a world lost to 
neoliberal reason is sometimes evident in media analysis that depicts "mainstream media" or to use Nick Couldry's (2003) more helpful term "centring media" - as politically hopeless spaces. To be fair, no one would dismiss the political significance of centring media, even in analyses that see the construction of an alternative media infrastructure as central to any counter-hegemonic project. However, I think a certain critical pessimism can be discerned in the sense that there isn't much left to say about the ideological disposition of traditional journalism that is theoretically interesting or suggestive - as if any critique of "big media" is merely repeating points that everybody knows already. These are impulses I try to avoid in my work, by gesturing towards a form of ideology critique (see Phelan 2016) that tries to avoid simply documenting the wrongness of journalistic and media representations, and instead hones in on critically understanding the political conditions that makes those representations possible.

I've rambled a bit, but to answer your most provocative question: no, we should not dispense with the term "neoliberalism", because, even if we did, we'd have to quickly deploy an alternative name ("capitalism" is clearly one!) for giving political shape to social, cultural and economic patterns that transcend any single empirical horizon. I think the signifier neoliberalism is as good as any other for naming some of the most oppressive features of the dominant social order.

At the same time, critical scholars need to be more careful about how we use the name, and our desire to construct neoliberalism as the political antagonist should be tempered by the need to give the concept a sharper theoretical and analytical register. I think this kind of work becomes particularly important as the term becomes more visible in centring media discourses, as I think it has done in recent years, both in the form of a left articulation of the term and a reactionary discourse that derides it as the fanciful creation of left conspiracy theorists. Debates about what neoliberalism "is" become part of a mediatized "politics of the present", the site of a political struggle between those who want to imagine, and those who want to close down, the possibility of a different kind of social order.

SIMON DAWES: Do you think that the tendency to reduce neoliberalism to a bogeyman concept is particularly recurrent among scholars based in the UK and Ireland (as opposed to those in Australia and New Zealand, for instance)? How do you account for the differences in theoretical approach between scholars in each hemisphere?

SEAN PHELAN: I can't speak about the Australian context with much authority - my engagement with the academic scene there has been slight. I feel more of an affinity with the UK academic culture, though my visits there have been pretty infrequent. In general, I am not inclined to read any theoretical differences on national lines. It's not something I've discerned in any kind of patterned way and, even if we can identify particular institutional milieus in different national contexts, I think one is just as likely to come across intra-national differences as cross-national ones. What I do sense are scholarly and popular understandings 
of neoliberalism that are strongly shaped by national collective memories and narratives. For example, one of the tendencies in the New Zealand context - at least in popular media representations - is to represent neoliberalism as something that happened in the radical experiments of the late 1980s and early 1990s. I think that a collective desire to disidentify with that period helps explains the version of post-ideological neoliberalism strategically articulated by the different governments led by John Key since 2008. At the same time, the country's media system is in a much more chronic, advanced neoliberal state now than it was in the 1980s and 1990s, as illustrated by the recent encroachment of vulture capital funds into an already deeply corporatized media system. I see the cultural effects of this media regime clearly in the classroom. Student identification with concepts like "public service media" can be weak - and unsurprisingly so because, with some notable exceptions (such as Radio New Zealand), they struggle to find exemplars in the media culture.

SIMON DAWES: To understand neoliberalism, you draw on a number of theoretical approaches: not just the broadly Marxist and Foucauldian approaches so often treated as incompatible, but also the discourse approach of Laclau and the field theory of Bourdieu. To what extent do you see these various approaches as commensurable, and could you elaborate on their respective strengths and weaknesses for developing a theoretical account of neoliberalism?

SEAN PHELAN: The engagement with Marxist and Foucauldian approaches is mainly covered in the first chapter of the book, as part of an initial overview of the existing media and communication studies literature. Insights from both traditions inform different aspects of the argument (how could they not), though neither is drawn on in any kind of systematic way. Conceptualizing neoliberalism as a distinct kind of capitalist formation is probably strongest in the chapter about Ireland. A Foucauldian emphasis on neoliberalism as a system of governmentality informs my discussion of the mediatized dynamics of the so-called "climategate" scandal, where climate change scientists were represented as wicked figures manipulating the science for their own self-interested ends.

The two theoretical influences centring the overall argument are Laclau/Laclau and Mouffe's discourse theory and Bourdieu's field theory. One could say a lot more, in a theoreticist vein, about the logic - and potential problems - of combining both theories. But the basic argument for bringing them together is straightforward. Laclau is a political theorist whose work focuses on developing an ontological-level analysis of how society is politically constituted, while Bourdieu is a sociologist who is similarly attentive to the political nature of the social, but suspicious of ontological-level theorizing that is ungrounded in the empirical. That shorthand justification risks reinforcing some of the stereotypes associated with Laclau's work, because, contrary to the perception that discourse theorists are indifferent to material questions, or fixated with contingency, I use discourse theory to explore how neoliberal logics have been materially sedimented into existing social and media practices. The concept of sedimentation, which Laclau appropriated from Husserl, is actually central to my argument 
for combining Laclau and Bourdieu. Concepts like field, habitus and doxa give us a richer vocabulary for understanding the dynamics of social sedimentation. Laclau is not really interested in formulating an empirical analysis of sedimented social practices - in fact, he's quite explicit that his work is situated, and therefore should be appraised, at the level of social ontology.

The book's theoretical rationale is mainly discussed in chapters 2 and 3. One of the things I consciously avoided doing in subsequent chapters was dutifully draping the analysis in discourse theory/field theory jargon; I was wary of subordinating each empirical context to theoretical discourses, where everything needed to be explained in terms of "logics of equivalence", "logics of difference", and so on. I realise that some readers might have anticipated a more programmatic methodological approach, but the influence of Laclau and Bourdieu is there throughout the book - imbued in a recognition of the political nature of media practices and their embodiment in sedimented forms that simultaneously disavow their political bearings.

SIMON DAWES: Your own development of this discourse-field approach to understanding neoliberalism relies, more specifically, on Glynos and Howarth's particular version of discourse theory and their privileging of logics, as well as the work of Billig on banal rhetoric, and of Couldry on media rituals. How exactly do you draw on these disparate perspectives for your account of neoliberalism?

SEAN PHELAN: Jason Glynos and David Howarth's book, Logics of Critical Explanation in Social and Political Theory, has been a big influence on my work - it's a text I keep recommending to people who want to know more about the methodological implications of discourse theory. They rework Laclau's concept of discursive logics as a triadic distinction between political logics, social logics and fantasmatic logics, which also informs my justification for linking Bourdieu and Laclau. I don't apply their methodological schema in a systematic way, but my use of the concept of neoliberal logics follows their emphasis on the articulated nature of any social order or regime. I also like how they articulate a mode of critique that stresses the necessity of attending to agents' own self-interpretations of their practices, but which then makes the crucial methodological move of examining the "conditions of possibility" of those interpretations

I discuss Nick Couldry's work on media rituals, and Michael Billig's work on banality, in chapter 8, though these influences are discernible elsewhere in the book. Couldry (2003) acknowledges a theoretical debt to both Bourdieu and Laclau in his book on media rituals, and he also pays a passing nod to Billig - because of the clear affinities between Billig's concept of banal ideological rhetoric, and Couldry's own analysis of the power of media naming. I introduced these concepts in chapter 8 because of how they resonated with my analysis of the role of mediated dynamics in disseminating the category of "the Celtic Tiger" as a way of talking about Irish economic and social transformation in the 1990s and 2000s. I 
also briefly linked my use of Billig and Couldry to Timothy Mitchell's work on the emergence of "the economy" as a social category. The chapter purposefully rambles across different national and international contexts, but the thread keeping it together was examining the mediated dynamics of a social formation where politics becomes subordinate to the objective of serving the economy.

SIMON DAWES: You also draw on Laclau and Mouffe's distinction between "politics" and the "political". Could you explain this distinction and its pertinence for a critique of actually existing neoliberalism?

SEAN PHELAN: Laclau and Mouffe's distinction between "politics" and "the political" is their version of Heidegger's distinction between ontic-level and ontological-level analysis. In simple shorthand terms, "politics" signifies a sedimented world of political institutions and practices; what we can broadly equate with Bourdieu's notion of "the political field" as a regional social domain. In contrast, the concept of "the political" signifies a much wider horizon. The entire constitution of society - in effect, all of Bourdieu's social fields - is theorized as a site of politics, in that the organisation of any social institution and practice is regarded as contestable.

One way in which this distinction is helpful to the critique of "actually existing neoliberalism" is that it gives us a useful critical lens for examining the neoliberalized character of journalistic and media practices that are disavowed as political, not to mind neoliberal. People have been talking about the "politics of representation" for decades, but I am fascinated by the enduring authority of a journalistic doxa that constructs journalism and politics as discrete phenomena. The distinction between politics and the political is an especially productive frame for analysing journalism, because the journalistic field is, in a sense, the space of "politics of usual"; the temporal and spatial orientation of the field is embedded in the world of the given, even while simultaneously orientated towards novelty. At the same time, the journalistic field is also implicated in the logic of the political, for the simple reason that any radical challenge to the existing social order - if it wants to gain popular traction - needs to be made visible in centring media spaces. I use this theoretical couplet to argue that interrogating the sedimented authority of neoliberal logics necessitates a critique of sedimented media practices, since the two analytical domains are interwoven in a regime of mediated neoliberalism.

This is not an argument that I explored in the book. But I should say that I am wary of work that can harden the distinction between politics and the political, by juxtaposing the dull world of institutional politics with a radical horizon of ontological possibilities. In a way, my book is all about trying to explore a space in-between these two analytical levels, by getting at questions that politicize the condition of centring media. One recent book that I would recommend on this point is Lois McNay's, The Misguided Search for the Political, which questions the privileging of ontology in recent critical political theory. McNay (2014) is not 
dismissive of the work of Laclau, Mouffe and others, or the analytical value of ontological perspectives. However, she does capture the limitations of a kind of formalist analysis that explains politics in terms of some prefabricated ontological commitments.

SIMON DAWES: You seek to identify potential sites of cultural politics within neoliberalized media regimes, so as to better elucidate the logics that might be politically acted upon in the name of a radically different kind of media and political culture. Could you give an example of the kind of cultural politics you have in mind?

This is a good question and, aside from a brief signposting of possibilities in the final chapter, it's not one I answer in any kind of systematic way in the book. My focus was on critically analysing a terrain of neoliberalized media practices, rather than documenting possible counter-hegemonic alternatives, or even highlighting cases where neoliberal reason is successfully challenged in centring media. I wanted to hone in on sedimented practices that often escape close analysis in discussions of the relationship between neoliberalism and media. In most popular and academic discourse, the impact of neoliberalism on media culture is primarily conceptualised in terms of the detrimental effects of corporate ownership. The latter perspective is of course hugely important, but I think it can miss some of the deeper, often unconscious, resonances between neoliberal logics and media practices.

As for examples of the kind of cultural politics I have in mind, let me answer my reflecting on some of the arguments in the book. Take, for instance, the relationship between journalism, "banal nationalism" and - to adapt Billig's (1995) term - banal neoliberalism. I think most journalists who report on political economy do not consciously do so from a neoliberal perspective. However, they typically privilege the figure of the national economy, even in cases where its fortunes are clearly tied to the fate of other economies - and even in scenarios where the notion of a "national" economy is something of a misnomer, because of the dependence on transnational capital. The privileging of the nation is similarly reproduced in political journalism's focus on national politics, and in journalistic discourses that evaluate the success of national governments based on their ability to manage the national economy. The result is a realist journalistic habitus that is locked into a particular articulation of the relationship between the national and the transnational (one primarily orientated towards evaluating the competitive standing of "our economy" vis-à-vis other economies), which stifles the political question of how nations might relate to each other differently. I illustrated this point in chapter 5 of the book, by showing how the representation of the Irish crisis in the journalism of The Irish Times' political editor, Stephen Collins, was stuck in a discourse that privileged the signifiers of the "national interest" and "the economy" and which had essentially nothing to say about the wider capitalist crisis, or the emergence of counterhegemonic tendencies such as Occupy Wall Street. This is why I quipped that, following Rancière, Collins might be more accurately described as the paper's "police" editor, because he cannot see beyond the given ways of being, seeing and doing politics. 
My point here is that we need to politicize the disposition of the journalistic field and habitus as part of any lucid discussion of how neoliberal and national logics come together in a regime of "neoliberal nationalism". In a utopian spirit, it summons the need for media and journalistic practices that restage the relationship between "here" and "elsewhere" and which enable the possibility of a transnational politics no longer governed by the imperatives of neoliberal capitalism.

\section{References}

Billig, M. (1995). Banal nationalism. London: Sage.

Couldry, N. (2003). Media rituals: A critical approach. London: Routledge.

Fisher, M. (2009). Capitalist realism: Is there no alternative? London \& New York: Zed Books.

Glynos, J. \& Howarth, D. (2007). Logics of critical explanation in social and political theory. London: Routledge.

McNay, L. (2014). The Misguided Search for the Political. Cambridge, UK: Polity.

Phelan, S. (2014) Neoliberalism, Media and the Political, Hampshire: Palgrave Macmillan

Phelan, S. (2016). 'Reinvigorating ideology critique: Between trust and suspicion'. Media, Culture \& Society. 38 (2), 274-283

Sean Phelan works at Massey University's Wellington campus and has a $\mathrm{PhD}$ in Communications from Dublin City University. He teaches and researches in the field of critical communication and media studies. He is the co-editor of Discourse Theory and Critical Media Politics (2011, Palgrave Macmillan) and Scooped: The Politics and Power of Journalism in Aotearoa New Zealand (2012, AUT media). His book, Neoliberalism, Media and the Political, was first published in November 2014 by Palgrave Macmillan and will be published in paperback later this year.

Email: $\underline{\text { S.Phelan@massey.ac.nz }}$

Simon Dawes is the editor of Networking Knowledge - the Journal of the MeCCSA PGN, editorial projects \& website manager of Theory, Culture \& Society and Body \& Society, and editor of the media \& communication studies section of the Open Library of Humanities. He teaches at Université Paul Valéry, Montpellier, France. His research revolves around issues of media theory, history and regulation. Currently, he is writing a monograph based on his $\mathrm{PhD}$ thesis, Broadcasting and the Public-Private Dichotomy (forthcoming, Palgrave Macmillan).

Email: simondawes0@gmail.com 